\title{
Problems and Countermeasures of School-enterprise Cooperation in E-commerce Major
}

\author{
Xue Tian \\ School of Information Science and Technology \\ Taishan University \\ Taian, Shandong, China \\ tianx1122@163.com
}

\begin{abstract}
In order to improve the quality of e-commerce professionals and cultivate practical talents to meet the needs of the society, universities have discussed the mode of school-enterprise cooperation. At present, there are many universities that have carried out this mode, but the quality of training talents is uneven, which causes the attention of universities. This paper presents the current problems in the process of implementation of school-enterprise cooperation by analyzing the nature and characteristics of school-enterprise cooperation in e-commerce major. In view of the problems and from four aspects: the management, the course distribution, the social responsibility and the personnel stability, it puts forward the profound countermeasures of school-enterprise cooperation in e-commerce major.
\end{abstract}

Keywords—school-enterprise cooperation; deep fusion; applied talents

\section{INTRODUCTION}

The development of information technology has promoted the generation of e-commerce, which has made the traditional business model change. Today, e-commerce covers all walks of life, and all countries are developing and researching relevant professionals, aiming to develop talents with comprehensive abilities to adapt to the change. Since the end of the 20th century, China has begun to try to raise talents with skills of electronic commerce. Nowadays, almost all the national universities have opened professional e-commerce major. And Taishan University also opened it in 2006, and it has already experienced 10 years of exploration.

E-commerce talents are practical talents. It is difficult to cultivate students' practical ability relying on the theory of professional course in university, and it is also difficult for the experimental environment of the school to simulate the real external environment. In addition, the development of e-commerce is quite rapid, and the school cannot catch up with the development of the market environment in terms of capital investment and experimental environment upgrade. Therefore, cooperation with enterprises is a reasonable solution.

\section{CONNOTATION AND MODE OF SCHOOL-ENTERPRISE COOPERATION IN E-COMMERCE MAJOR}

The school-enterprise cooperation is a new type of education way for universities to cultivate adaptable talents, and improve the quality of training as well as promote employment rate. School combines with enterprise, giving play to their respective advantages. School carries out the theory knowledge teaching, while enterprise is responsible for training students' practical ability, so as to encourage students to combine theoretical knowledge and practical application. In this way, talents that are cultivated will not alienate from society, and they can rapidly adapt to the job after graduation.

TABLE 1 THE MODE OF SCHOOL-ENTERPRISE COOPERATION IN E-COMMERCE MAJOR

\begin{tabular}{|c|c|}
\hline Mode of Cooperation & Characteristics \\
\hline Classroom training & $\begin{array}{c}\text { In the training program, some practical courses are set up, with the } \\
\text { compulsory courses being the main ones. The enterprise arranges personnel } \\
\text { to enter the school to undertake it. For basic courses, the advantage is that it } \\
\text { is easy to manage and implement. }\end{array}$ \\
\hline In-campus practice base & $\begin{array}{c}\text { The university is to invest the creation of the laboratory, simulate the } \\
\text { practice environment, and students use the spare time to study in the } \\
\text { laboratory, operate some projects, with the enterprise tutors giving guidance. } \\
\text { The advantage is that it creates a space for students to cultivate their ability in } \\
\text { the campus and consolidate what they have learned. The disadvantage is that } \\
\text { the investment is great. }\end{array}$ \\
\hline Off-campus practice base & $\begin{array}{c}\text { Go to the enterprise training base for training or getting direct access to } \\
\text { the enterprise environment for actual combat, which applies to students who } \\
\text { have already mastered basic theories and skills. It belongs to the stage of the } \\
\text { transition from school to employing units. }\end{array}$ \\
\hline
\end{tabular}


At present, there are three main modes of cooperation between universities and enterprises: classroom training, in-campus practice base and off-campus practice base, as shown in table 1.

\section{ADVANTAGES OF SCHOOL-ENTERPRISE COOPERATION IN E-COMMERCE MAJOR}

Either in one way or in a variety of ways, the principles and characteristics of school-enterprise cooperation are similar.

\section{A. Cultivate Qualified Talents to Adapt to Market Environment}

The development of e-commerce is rapid, and the demanded technology is updated at any time. Employing units choose and employ persons who not only master the solid theoretical knowledge, but also master certain advanced technology. This kind of advancing with the times is difficult to be grasped just relying on school. However, enterprises have direct contacts with the market environment, and it can intuitively reflect the realistic requirement of employment market. When training students' ability, it can avoid a lot of detours.

\section{B. Create a Realistic Environment for Cultivating Talents}

Schools use classrooms or the experimental environment to foster talents, but the essence of the experimental environment is just simulation. No matter how close it simulates the real environment, there is always a gap comparing with the realistic environment, so it is difficult to achieve the ideal effect of cultivation. By means of cooperation between universities and enterprises, enterprises can restore the realistic environment, or directly bring the student to the realistic environment. Students combine theoretical knowledge with the actual situation in the learning process, to use what they have learned.

\section{Promote Each Other and Take What They Need}

The cooperation between schools and enterprises is not the relationship of one party serving the other, but about mutual needs and win-win outcomes. On the one hand, enterprises provide training services for schools, cultivate talents and teachers, and improve the ability of schools to "produce and study". On the other hand, the school also has cultivated talents for the enterprise. The value of talent is infinite. Enterprises that can effectively identify those who have the potential in training process will effectively reduce the recruitment and training costs.

\section{PROBLEMS OF SCHOOL-ENTERPRISE COOPERATION IN E-COMMERCE MAJOR}

The advantages of school-enterprise cooperation are obvious, which are the main trend of the teaching methods in e-commerce major. However, in the actual operation process, it also reveals some certain problems.

\section{A. Thinking of School-enterprise Cooperation as a Simple Addition of Schools and Enterprises}

Some of the universities that pioneered the model of school-enterprise cooperation have achieved certain results, and many other institutions have followed them, which, to some extent, caused the abuse of this model. School-enterprise cooperation is not a simple "school" + "enterprise", but a deep fusion of the two. Schools and enterprises should work together to develop training programs around the goal of talent training, to make clear the responsibilities of the two sides and to know how to connect them. Otherwise, students will be unsettled on the course, and the cultivation of students will become disjointed and fail to achieve the desired effect.

\section{B. Thinking of Cultivation as a Simple Copy of Talents}

The essence of school-enterprise cooperation should be to combine theory with practice, so that students can reflect on their knowledge in practice and understand theoretical learning more thoroughly. Therefore, cultivation should be about the students' learning ability, not the single skill. In particular, for universities, the cultivation of students' ability is more important than the cultivation of technology. However, because of the characteristics of the enterprise profit-oriented organization, many companies are too urgent for success in the cooperation process, with pure technical teaching instead of actively guidance or treating students as cheap labor, which causes student's disgust and reaches an opposite effect.

\section{Imperfect Management System}

Although schools will draw up detailed contracts when working with companies, many problems arise in the implementation process. For example, if schools arrange students to be at off-school practice bases, the schools give the management of students completely to the enterprises or assume it jointly with enterprises. Whether students' safety accidents are responsibilities of the enterprises or that of the schools is hard to be defined. In addition, the practice environment as well as the content itself is relatively loose and difficult to be completely clear, which makes it difficult to quantify the evaluation of teaching quality. Generally, the school-enterprise cooperation agreement is signed at least four years. If problems are found and it cannot be suspended, it will cause profound influence to students.

\section{V.COUNTERMEASURES OF SCHOOL-ENTERPRISE COOPERATION IN E-COMMERCE MAJOR}

In order to implement the school-enterprise cooperation mode in e-commerce major better, universities should study deeply the cooperation mechanism between schools and enterprises, mainly from the following aspects. 


\section{A. In the Management, the Main Status of Universities Cannot Be Changed}

No matter what kind of form is taken, the main status of the university is invariable. Universities make plans for students' training as the main party, and the enterprises participate in making suggestions and implementing them. In the process of implementation, involving the school-enterprise cooperation, whether it is in or off campus, it is the responsibility of universities to participate to exercise their rights and obligations, and students cannot be brought completely to the enterprises. And the enterprises have relatively large right in services offering, and they have the obligation to accept the school system constraint and observe the school management norm. Training quality of the enterprises should be controlled, for example, when signing a contract, and there will be detailed evaluation standards, which should be made through several aspects, such as the student feedback ratings, assessment of students' abilities, and employment situation. If the enterprise cannot meet the requirements, the schools have rights to suspend the contract and execute the alternatives.

\section{B. The Proportion of In-school Courses and Enterprise Training Courses Should Be Appropriate}

Although universities have been promoting training practical and applied talents, the practical and applied talents are not the same as technical talents. It should be clear that the goal of talents cultivation in universities is different from the talents training goal of higher vocational college. Students cannot be trained into pure technical workers. In terms of curriculum properties, practical training courses are actually the consolidation of theoretical courses, helping students to understand theoretical knowledge better, and draw inferences about other cases from one instance in the case of linking theory with practice. Therefore, when setting up the course, schools should concentrate on the talent cultivation goal strictly, pay attention to the course credits proportion of theory and practice, and arrange training courses that have something to do with theoretical courses. For example, schools, in the previous stage, assume the theory course named "Network Program Design Basis", while enterprises, in the latter phase, assume the training course named "Network Program Design Practice" in the form of projects. In addition, we should focus on guiding students' understanding of the functions of different courses and connecting the knowledge system together.

\section{Enterprises Should Strengthen Their Sense of Social Responsibility}

In the pursuit of maximizing its own profit, enterprises should also be able to define its social role. Since working with the school to cultivate talents, they should take certain social responsibility. When cultivating talents, enterprises should not rush to seek for success. They should focus on the long-term result, and pay attention to the cultivation of students' ability, so as to improve the quality of recruitment and the cooperative relationship with universities.

\section{Enterprises Should Ensure the Stability of Their Teaching Staff}

Due to some nature of the enterprise, the turnover rate is relatively high. And students need a stable teaching troop. Frequent change will affect the continuity of students' understanding of the knowledge system. Besides, universities generally need enterprises to specify a guide member involved in the whole process, about four years. Therefore, enterprises should control the turnover of such personnel in a certain way, and this stability also requires universities and enterprises to make a definite agreement in the contract.

\section{CONCLUSION}

The school-enterprise cooperation in e-commerce major is an inevitable trend which has clear positive significance for students, universities and enterprises. However, how to carry out it will affect the quality of the school-enterprise cooperation, so the school-enterprise cooperation mechanism must be studied for its expected result. The responsibilities of both sides should be clear. All working process should be standardized. These two are inevitable requirements for the implementation of school-enterprise cooperation. Only all the work is in place, school-enterprise cooperation can play an effect of "1 $1>2$ ", and it can produce practical talents with better quality.

\section{REFERENCES}

[1] Wang Minxi, Wang Xinzhuang, Li Zhigang., Research on university-enterprise cooperation model of e-commerce practice teaching, E-commerce. 09(2011) 82, 92.

[2] Wang Wei, Wang Dan, Hu Yanling, Research on the mode of cooperation between e-business school and enterprises for e-business major, taking employment as the guidance, E-commerce. 12(2014) 87-88.

[3] Xing Saipeng, Tao Meisheng, The research of the system of faculty in applied technical undergraduate colleges and universities, based on the perspectives of "the integration of production and education, and the university-enterprise cooperation", Vocational \& Technical Education Forum.10(2014) 4-8. 